\title{
Individual, gender differences and corona: The relationship between personality traits and gender differences with corona self-care behaviour
}

\author{
Sahar Pouyan Fard ${ }^{1}$, Amir Abbas Taheri ${ }^{1}$, Mahdiyeh Ghvami ${ }^{2}$, Seyed Mojtaba Ahmadi ${ }^{3}$, Mohsen \\ Mohammadpour ${ }^{1}$ \\ 1-MSc in Clinical Psychology, Department of Clinical Psychology, Kermanshah University of Medical Sciences, \\ Kermanshah, Iran. \\ 2- MSc in Family Counseling, Department of Counseling, Kharazmi University of Tehran, Tehran, Iran. \\ 3- Assistant Professor, Department of Clinical Psychology, Kermanshah University of Medical Sciences, \\ Kermanshah, Iran. \\ Corresponding Author: Mohsen Mohammadpour \\ E-mail: mohammadpour5711@gmail.com
}

Received: 06/05/2020 Accepted: 01/08/2020

\begin{abstract}
Introduction: Currently, the corona virus has spread all over the world and has left various psychological effects on people in the community. In the meantime, some people are more caring about their behaviors, which can be for a variety of reasons.

Aim: The aim of this study was to investigate the relationship between personality traits (conscientiousness and extraversion) and gender differences with self-care behaviors in the community of Kermanshah.
\end{abstract}

Method: In this descriptive-correlational study, 304 adults in Kermanshah in 2020 were selected by convenience sampling method. Participants responded online (WhatsApp) to the Extraversion and Conscientiousness subscales of the short form of the 60-item Neo Questionnaire and the Self-Care Behavior Questionnaire. Data analysis was performed using SPSS-25 and linear regression analysis.

Results: The results showed that in the first model, among the studied variables, gender was the best predictor of self-care. Gender 0.09 explained the changes in self-care variable $(\mathrm{P}<0.001$ and $\mathrm{F}=17.30$ ). In the second step, the variables of gender and conscientiousness were included in the study. These two variables together predicted 0.14 of the variances of the self-care variable $(\mathrm{P}<0.001$ and $\mathrm{F}=13.98)$.

Conclusion: These results showed that individuals with conscientious characteristics, as well as women, were more likely to follow corona-related self-care behaviors. These results will have practical implications for the development of interventions for current and future crises.

Keywords: Corona virus, Personality traits, Conscientiousness, Extroversion, Gender

How to cite this article : Pouyan Fard S, Taheri AA, Ghvami M, Ahmadi SM, Mohammadpour M. Individual, gender differences and corona: The relationship between personality traits and gender differences with corona self-care behaviour. Shenakht Journal of Psychology and Psychiatry. 2020; 7 (4): 67-77 .URL: http://shenakht.muk.ac.ir/article-1-961-en.pdf

Copyright (C) 2018 the Author (s). Published by Kurdistan University of Medical Sciences. This is an open access article distributed under the terms of the Creative Commons Attribution-Non Commercial License 4.0 (CCBY-NC), where it is permissible to download, share, remix, transform, and buildup the work provided it is properly cited. The work cannot be used commercially without permission from the journal. 


\title{
تفاوتهاى فردى، جنسيتى و كرونا: رابطه بين ويزگىهاى شخصيتى و تفاوتهاى جنسيتى با رفتار هاى خود مر اقبتى مرتبط با كرونا
}

\author{
سحر يويان فرد'، اميرعباس طاهرى'، مهديه قوامى '، سيد مجتبى احمدى '، محسن محمد يور' \\ ا.كارشناس ارشد روانشناسى بالينى، گروه روانشناسى بالينى، دانشكاه علوم يزشكى كرمانشاه، كرمانشاه، ايران.

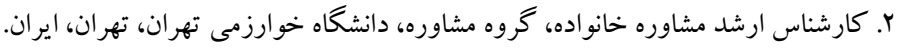

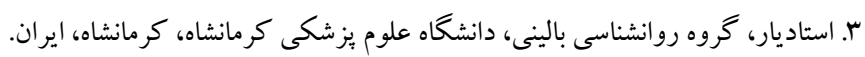 \\ ايميل: mohammadpour5711@gmail.com \\ مولف مسئول: محسن محمديور
}

مقدمه: در حال حاضر، كرونا ويروس تمام دنيا را فرا گرفته است و بر افراد جامعه اثرات روان شناختى مختلفى را بر جاى كذاشته

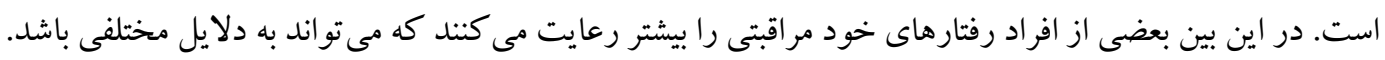
هدف: اين يزوهش با هدف بررسى ارتباط بين ويز گیىاى شخصيتى (وظيفه شناسى و برون گرايى) و تفاوتهاى جنسيتى با رفتارهاى خود مراقبتى در جامعه شهر كرمانشاه انجام كرديد.

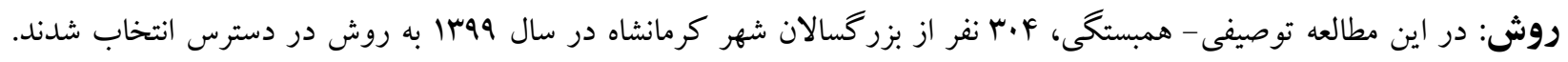

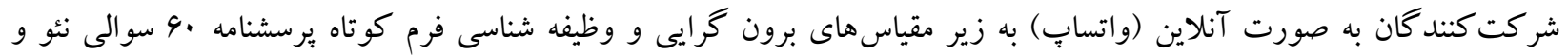

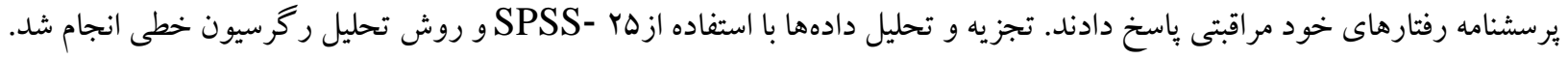
يافتها: نتايج نشان داد در مدل نخست از ميان متغيرهاى مورد مطالعه جنسيت بهترين متغير بيش بين خود مراقبتى بود. جنسيت •/9.9.

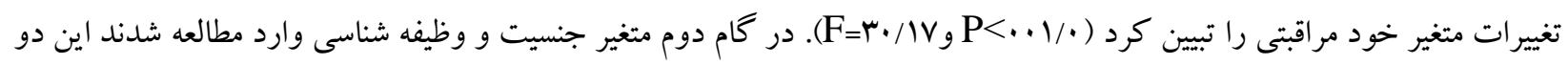

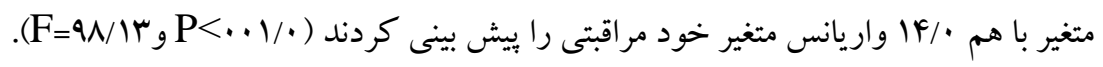
نتيجه كيرى: اين نتايج نشان داد افراد با ويزگ هاى وظيفه شناسى و همجنين زنان، رفتارهاى خود مراقبتى مرتبط با كرونا را بيشتر

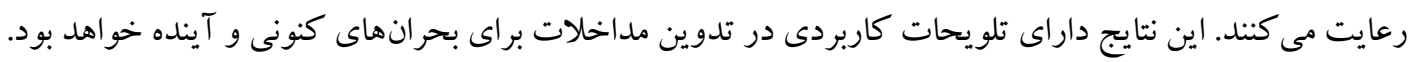
كليدوازهها: كرونا ويروس، ويز گى هاى شخصيتى، وظيفه شناسى، برون گرايى، جنسيت 
r.r.r.

مقله

.$(Y \cdot Y \cdot$

در ابتداى سال نو ميلادى ·r.r.r. خبر ابتلاى جندين نفر به با توجه به اينكه تاكنون واكسنى مؤثر براى اين ويروس ساخته نشده است، بهترين راه جهت مقابله با اين بيمارى، اجتناب از آلودگى و بيش گيرى از سرايت آن است. اكثر لهر

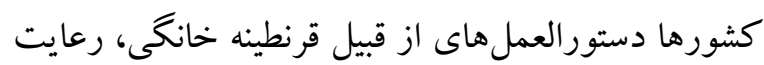
فاصله كذارى اجتماعى، شستوشوى مكرر دستها و و استفاده از زلهاى ضدعفونى كننده را توصيه مى كنند

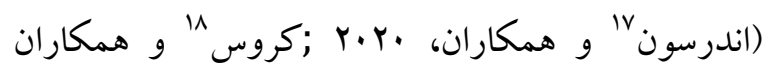
(Y.Y. و حتى در بعضى كشورها محدوديتهاى سنگينى براى كاهش سرعت و تأثير كرونا ويروس اعمال شده

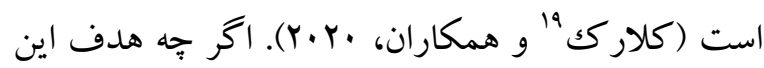
يروتكلها بيشخيرى و كنترل بيمارى است و مطالعات

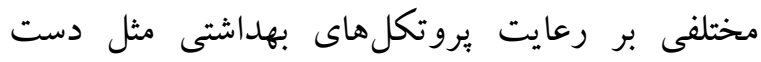

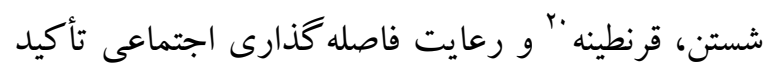

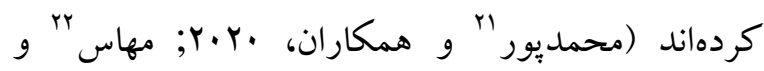

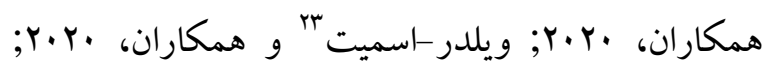

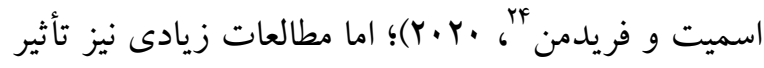
بالقوه آنها را در سلامت روان از قبيل اضطراب و افسردگى و استرس و حتى خودكشى بررسى كردهاند

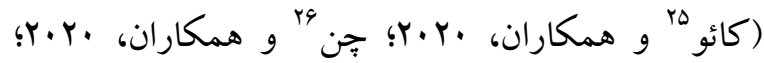
كونسالس

\footnotetext{
13 - Anger

${ }^{14}-\mathrm{Bao}$

15- Kim\& Choi

16. Yang

17- Anderson

${ }^{18}$ - Krous

${ }^{19}$ - Clark

${ }^{20}$ - Quarantine

21 - Mohammadpour

22. Mahase

23 - Wilder-smith

24 - Smith-freedman

25 - $\mathrm{CaO}$

${ }^{26}$ - Chen

27- Gonçalves
}

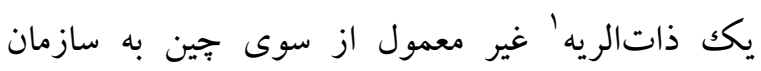
بهداشت جهانى باعث معرفى نوع جديدى از كرونا'

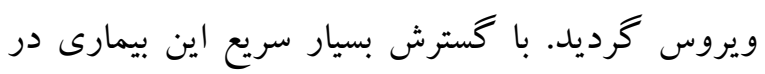
جين و ساير نقاط دنيا، نغرانى و اضطراب مرتبط با اين

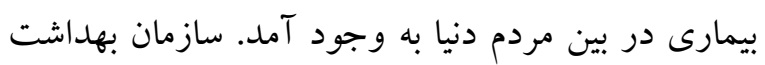
جهانى طى اطلاعيهاى، شيوع اين ويروس را عامل وضعيت اضطرارى بهداشت عمومى در سرتاسر جهان

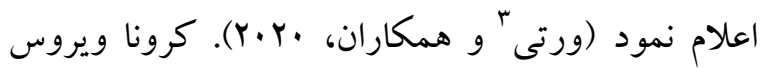
قدرت سرايت بالايى دارد به طورى كه به طور ميانكين هر شخص مىتواند سه نفر ديخر را مبتلا كند (ورتى و

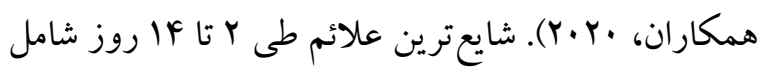

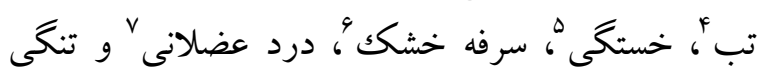

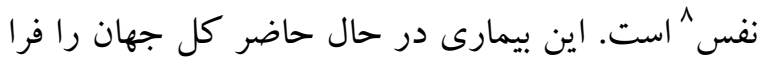
كرفته و باعث ابتلاى ميليونها نفر در دنيا شده است

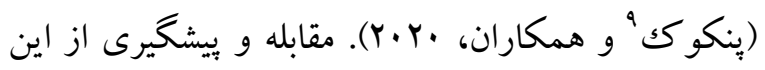

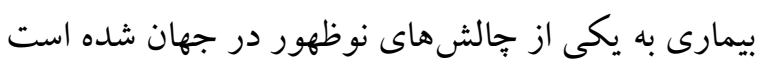
و اثرات مختلفى بر كاركردهاى مختلف افراد كذاشته

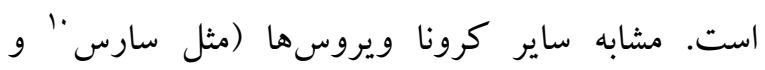

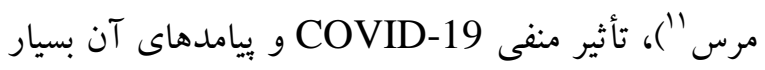
گسترده است، از جمله نتايج منفى در سلامت روان،

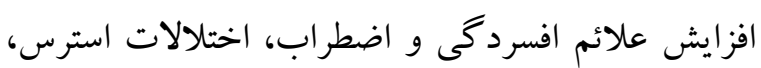

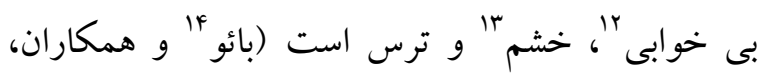

\footnotetext{
1. Pneumonia

2. Corona

3 - Verity

4- Fever

5 - Fatigue

6 - Dry cough

7- Muscular pain

${ }^{8}$ - Shortness of breath

9 - Pennycook

${ }^{10}$ - Sars

${ }^{11}$ - Mers

${ }^{12}$ - Insomnia
} 


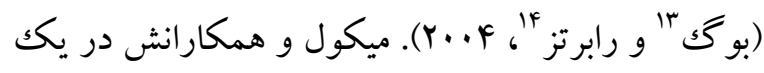
مطالعه به بررسى ارتباط بين ويز گیىهاى ضد اجتماعى و ورتو يايبندى به اقدامات مهار و كنترل كرونا ويروس برداختند. نتايج مطالعه آنها نشان دادند كه ويزگ كىهاى ضد اجتماعى، به ويزه سطح همدلى يايينتر و سطح بالايى احساس بى تفاوتى به ديخران، كلاهبردارى 10 و و

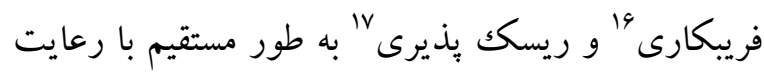
كمتر دستور العمل ها و اقدامات مهارى همراه بودند (تايلر

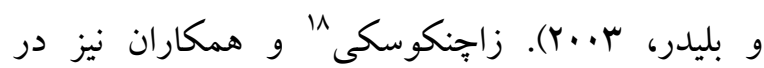
مطالعهاى بر روى به بو نفر با تأكيد بر شخصيت و تفاوتهاى فردى در ادراكى موقعيت كرونا ويروس (هشت موقعيت: وظيفه و خدمت

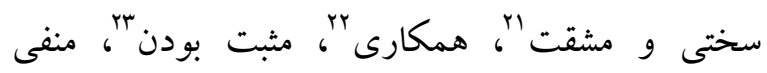

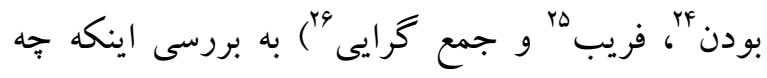
كسانى محدوديتها براى كاهش كرونا ويروس را ران رعايت مى كنند برداختند. نتايج مطالعه آنها نشان داد كه ادراكك متفاوت افراد از موقعيت كرونا ويروس نسبت به صفات شخصيت واريانس بيشترى از يايبندى به محدوديتها را تبيين كردند. همجنين افراد با نمره يايين در توافق يذيرى و صفاتى همجون ضداجتماعى و خودشيفتگى به احتمال كمترى محدوديتهاى اعمال

13- Bogg

14 - Roberts

15 - Scam

16- Deception

${ }^{17}$ - Risk-taking

${ }^{18}$ - Zachenkowski

${ }^{19}$ - Duty and service

${ }^{20}$ - Wisdom

21- Hardship

22 - Cooperation

23 - Positiveness

${ }^{24}$ - Negativeness

25 - Deception

26 - Collectivism
براى مثال كايو' و همكاران كزارش كردند كه راهكارهاى محافظتى توصيه شده در مقابل كرونا ويروس از قبيل خود انزواى و قرنطينه خانكى اثرات منفى بر

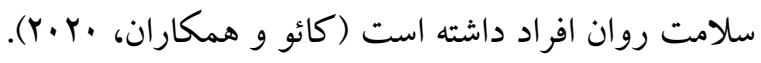

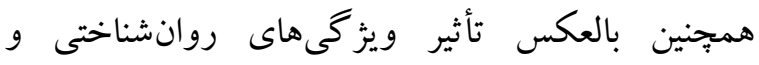
سلامت روان در موفقيت يا شكست در پيايبندى به

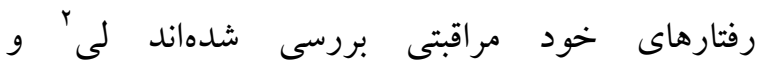

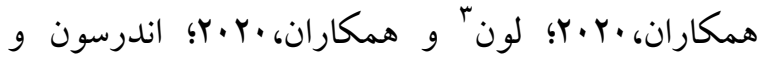

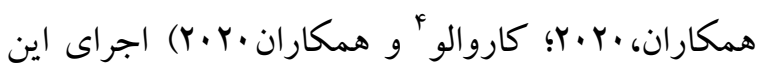
يروتكلها و سياستها در سطوح مختلف يزشكى و شخصى منجر به نرخهاى متفاوتى از ساز كارى و بيروى لرو از آنها در بين افراد شده است (ميكله ه همكاران، .Y.Y. بيروى از توصيهها مىتواند ناشى از عوامل مختلفى از جمله تفاوتهاى فردى و و جنسيتى لباشد. مطالعات نشان دادهاند كه صفات شخصيتى با رفتارهاى

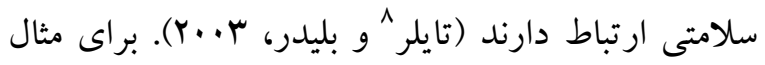
افرادى كه نمرهى بالايى در روان رنجور خويى " دارند، اغلب درباره سلامتىشان نگراناند؛ بنابراين به احتمال بيشترى رفتارهاى سلامتى را به درستى به كارمىبرند

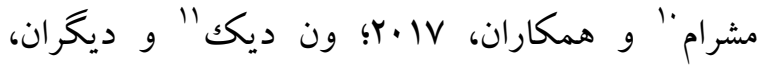

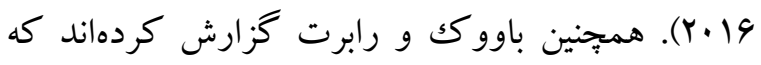
وظيفه شناسى "r با رفتارهاى سلامتى نظير اجتناب از باز رفتارهاى جنسى برخطر و سوء مصرف مو اد ارتباط دارد

\footnotetext{
1 - Qio

2- $\mathrm{Li}$

3 - Luun

${ }^{4}$ - De Francisco Carvalho

5 - Meguel

${ }^{6}$ - Individual differences

7- Gender

8 - Tyler

9 - Neuroticisim

${ }^{10}$ - Meshram

${ }^{11}$ - Van Dijk

${ }^{12}$ - Conscientiousness
} 
به هر دليلى از شركت در مطالعه و ير كردن برسشنامه انصراف دادند از مطالعه خارج شدند. روش كردآورى دادهها با توجه به إيدمى بيمارى كرونا ويروس و قابليت سرايت زياد آن از طريق شبكههاى مجازى ( واتساب) به صورت انلاين صورت گرفت. بعد از تاييد كميته اخلاق دانشگاه علوم بزشكى كرمانشاه، سوالات به صورت آنلاين طراحى شدند. سبس لينك مستقيم برسشنامههاى آنلاين از rاتا ها ارديبهشت ماه از طريق واتساب دردسترس ه人 نفر از جمعيت شهر كرمانشاه قرار گرفت. در نهايت بعد از حذف باسخهاى ناكامل و عدم ياسخ به سوالات باسخنامههاى كامل وارد

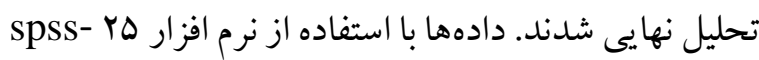
و به روش تحليل رگرسيون مورد تحليل قرار گرفتند.

ابزار يرسشنامه بنج عاملى شخصيت نئو (NEO-FFI): كاستا و كاستا و مكك كرى در سال 1919 فرم كو تاه يرسشنامه ينج عاملى را براى سنجش ينج عامل اصلى شخصيت طراحى كردند. اين پرسشنامه داراى •9 ماده است و صرفاً ينج عامل اصلى شخصيت را مىسنجد، در حالى كه فرم بلند آن علاوه بر ينج عامل، ابعاد سى گانه آن را نيز مىسنجد.

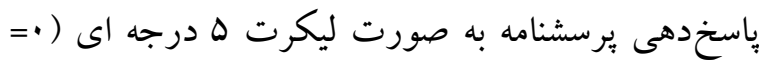
كاملا مخالفم تا F= كاملا موافقم) است. نمرات مقياس با جمع بستن با آيتم براى هر بعد و بس از نمره كذارى

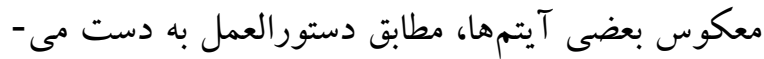
آيد. همبستخى بين فرم كوتاه و فرم بلند از له · • براى باوجدان بودن تا 119 · ·براى روان آزرده گرايى متغير

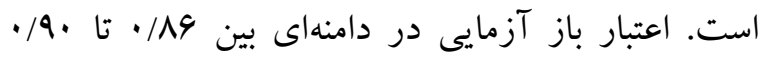
كزارش شده است. همجِنين همسانى درونى زير مقياس ها

\footnotetext{
${ }^{4}$ - NEO Five-Factor Inventory
}

شده را رعايت مى كنند (زاجنكوسكى' و همكاران، $(Y \cdot Y \cdot$ خود مراقبتى ب در همه گيرى ويروس كرونا مهم ترين عامل براى تحت كنترل در آوردن بيمارى است. اصول رفتارهاى خود مراقبتى مانند استفاده از ماسكى، فاصله كذارى اجتماعى و شستشوى مرتب دستها توسط برخى افراد رعايت و توسط برخى ديخر رعايت نمىشود و هايبندى به توصيهها براى كنترل بيمارى در بين افراد بسيار متفاوت است. بنابراين تبيين و توضيح اينكه جرا در طول همه گيرى اين ويروس بعضى افراد بيشتر از سايرين اين اصول و توصيهها را رعايت مى كنند حائز اهميت است. از ميان متغيرهاى كه نوع واكنش افراد را بيشبينى مى كنند مى توان به تفاوتهاى فردى و جنسيتى اشاره كرد. از طرفى ديخر ارتقاى سطح آكاهى و سلامت روان مىتواند راهى براى كاهش مشكلات روانشناختى مرتبط با اين ويروس باشد. با در نظر كرفتن اين مسائل هدف اين مطالعه تعيين ارتباط بين ويز گیىهاى شخصيتى و جنسيت با رفتارهاى خود مر اقبتى مرتبط با كرونا است.

روش طرح اين بزووهش از نوع توصيفى - همبستكى بود. جامعه مورد مطالعه شامل تمامى افراد شهر كرمانشاه در بهار سال 941" بودند. حجم نمونه بر اساس فرمول حجم نمونه براى مطالعات رگرسيون محاسبه شد (دابونت وبِلامَّ, 1991) كه در اين مطالعه F.r نفر بود. معيار ورود به مطالعه داشتن حداقل 11 سال سن، رضايت شخص براى ير كردن يرسشنامه و داشتن سواد خواندن و نوشتن براى ״ِاسخ دادن به سوالات يرسشنامه بود. همجينين افرادى كه

\footnotetext{
- Zachenkowski

${ }^{2}$ - Self-care

3 - Dupont \& Plummer
} 
به منظور تعيين قوىترين تبين كننده خود مراقبتى در بين

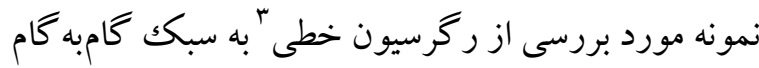

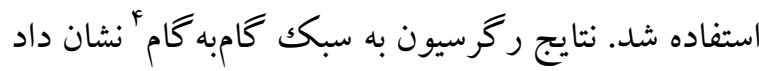
كه از بين متغيرهاى وارد شده در تحليل جنسيت (زن بودن) و وظيفهشناسى بهترين بيشبينى كنندهاى خود مر اقبتى در زمان شيوع كرونا مىباشند. همان طور كه در جدول نشان داده شده است در مدل نخست از ميان متغيرهاى مورد مطالعه جنسيت بهترين متغير بيشبين خود مراقبتى است جنسيت 9 × • تغييرات متغير خود مر اقبتى را

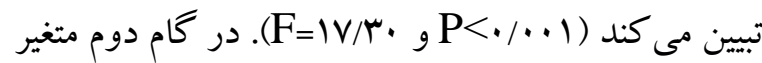
جنسيت و وظيفهشناسى وارد مطالعه شدند اين دو متغير با هم FF/ • واريانس متغير خود مراقبتى را بيش بينى

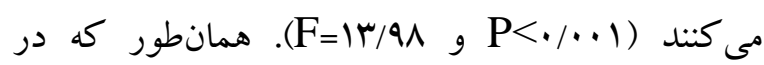
جدول نشان داده شده است جنسيت با بتاى ץ"// • بيشترين سهم و وظيفه شناسى با بتاى سץ/ • بعد از آن نقش مؤثرى در يِيشبينى خود مراقبتى در شرايط كرونا داشته اند. نتايج بدست آمده در جدول ا ارائه شده است.

3 - Linear regression

${ }^{4}$ - Step-by-step style regression

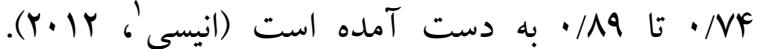

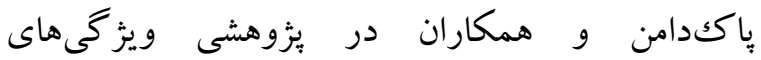
روانسنجى آن را بررسى كردند. در اين مطالعه از زير

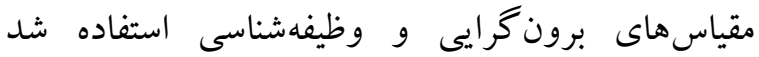
(ياككدامن و همكاران، 1991).

يرسشنامه رفتارهاى خود مراقبتى مرتبط با كرونا؛! اين يرسشنامه خود ساخته شامل ها سؤال كه رفتارهاى خود مراقبتى مرتبط با كرونا را در طيف ليكرت هـ درجه ایى از ا (خيلى زياد) تا ه (خيلى كم) مى سنجد( مثل: موقع بيرون رفتن نكات بهداشتى مثل بوشيدن ماسكك و دستكش را رعايت مى كنم). جمع نمرات طيفى از ها تا است كه نمرات بايينتر نشاندهنده رعايت بيشتر رفتارهاى خود مراقبتى است. آلفاى كرونباخ برسشنامه در مطالعه فعلى AV/ · بود. روايى اين پيرسشنامه توسط متخصصان سلامت، داخلى، عفونى و روان شناسان ارزيابى و تائيد شد. اين برسشنامهاى داراى سوا لاتى است كه عواملى نظير فاصله كذارى اجتماعى، استفاده از ماسك و رفتارهاى مرتبط با دست شستن را مىسنجد.

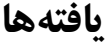

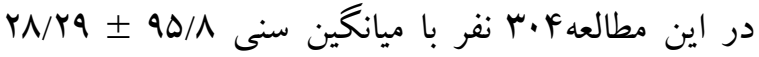
شركت كردند. كه از اين تعداد Yه نفر( •r/r درصد)

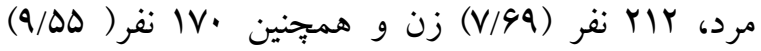
درصد مجرد و تحصيلات نيز r| نفر (و/ درصد) تحصيلات زير دييلم، 4 4 درصد (F/F ليسانس، VY نفر (YF درصد) كارشناسى ارشد، IM نفر (9/9) (9/9 درد ) دكترى بودند.

\footnotetext{
- Anisi

${ }^{2}$ - Corona related self-care behaviors questionnaire
} 


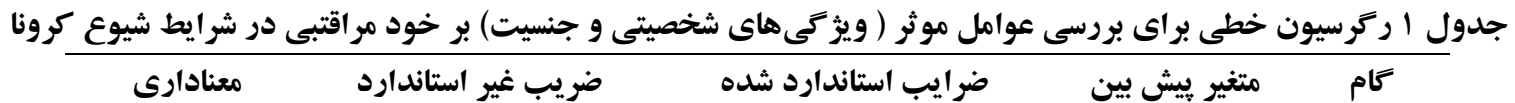

\begin{tabular}{|c|c|c|c|c|c|c|}
\hline سطح معنادارى & $\mathbf{T}$ & Beta & خطاى استاندارد & B & Model & Step \\
\hline $\mathrm{P}<\ldots \mathrm{l} /$ & $19 / 4$ & $\mu \nu /$ & $\Delta Q / 1$ & $94 / 9$ & جنسيت & كام اول \\
\hline $\mathrm{P}<\cdot / \cdot .1$ & $r q / 4$ & $r Y /$. & $\Delta \Delta / 1$ & $\Lambda r / 9$ & جنسيت & كام دوم \\
\hline$\% r$ & $11 / r$ & $r \mu /$. & $r \cdot / \cdot$ & $90 / \cdot$ & وظيفه شناسر & \\
\hline
\end{tabular}

فاصله كذارى اجتماعى را براى كاهش سرايت و كنترل آن توصيه مى كنند. يافتهاى اين مطالعه نشان داد كه بين برخى ويثز گیى هاى شخصيتى مثل وظيفه شناسى و همجِنين تفاوتهاى جنسيتى با رفتارهاى خود مر اقبتى كرونا رابطه وجود دارد. براساس يافتهاى اين بثوهش فقط fi در صد از رفتارهاى خود مراقبتى مرتبط با كرونا ناشى از ويز گیىهاى شخصيتى وظيفه شناسى و جنسيت (زنان) بود. اين يافتها همسو با ساير مطالعات بود (كلاركك و

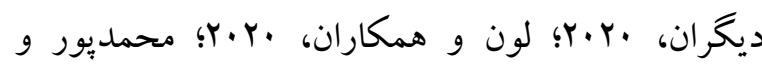

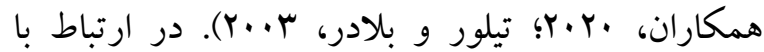
تفاوتهاى جنسيتى، جندين مطالعه تفاوتهاى جنسيتى در رفتارهاى ييشخيرانه براى اجتناب از سرايت بيمارى را

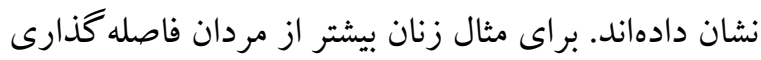
اجتماعى را تائيد مى كنند و بهداشت شخصى را بيشتر از

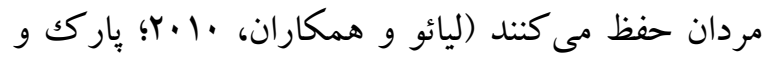
همكاران، · · (Y). موران و دل وال (Y) (Y) نشان دادهاند كه زنان بيشتر از مردان به احتمال بيشترى از شلوغى و

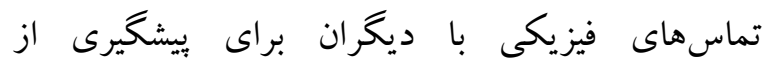

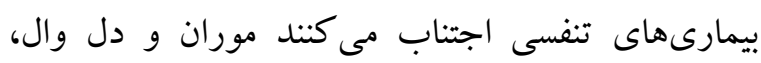

يافتهاى مطالعات قبلى در ارتباط بين صفات شخصيتى و بايبندى به رفتارهاى خود مراقبتى ارتباط بين ويز گحى هاى شخصيتى و رفتارهاى خود مراقبى را در مطالعه فعلى
نتايج رگرسيون به سبك كام به گام' نشان داد كه از بين متغير هاى وارد شده در تحليل جنسيت (زن بودن) و وظيفه شناسى بهترين بيش بينى كنندهاى خود مراقبتى در زمان شيوع كرونا مىباشند. همان طور كه در جدول نشان داده شده است در مدل نخست از ميان متغيرهاى مورد مطالعه جنسيت بهترين متغير بيش بين خود مراقبتى مىباشد جنسيت ·/9 · تغييرات متغير خود مر اقبتى را تبيين

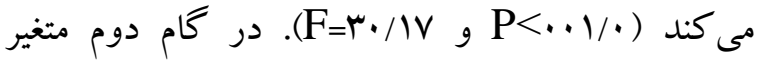
جنسيت و وظيفه شناسى وارد مطالعه شدند اين دو متغير با

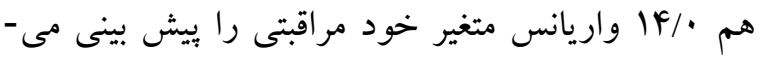

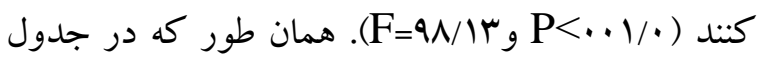
نشان داده شده است جنسيت با بتاى · • ب بيشترين سهم و وظيفه شناسى با بتاى • M ب بعد از آن نقش موثرى در بيش بينى خود مر اقتبى در شر ايط كرونا داشته اند. اين مطالعه با هدف بررسى رابطه بين ويزگ گهاى شخصيتى و تفاوتهاى جنسيتى با رفتارهاى خود مراقبتى مرتبط با كرونا انجام شد. همه گيرى كرونا ويروس تمام دنيا را فراكرفته است و بيشتر كشورها به خاطر سرايت بالايى اين بيمارى بروتكلهاى نظير استفاده از ماسك، ضدعفونى كردن و شستوشوى مكرر دستها و رعايت

\footnotetext{
1- Step-by-step style regression
} 
همكاران همسو است كه گزارش كردند از ميان ينج عامل بزرگك شخصيت فقط توافق بذيرى با پايبندى به

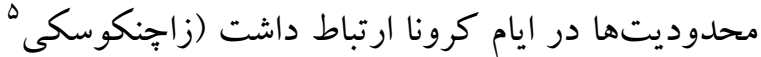

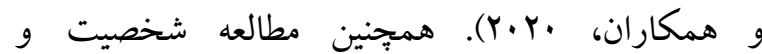
رفتارهاى فضايى روزانه نشان مىدهد كه افراد با وجدان از تعداد نسبتاً كمى از مكانها را در طول يكك روز بازديد مى كنند؛ بنابراين محدوديتهاى مثل قرنطينه كمتر آنها را آشفته مى كند. در مقابل افراد برون گرا گرايش دارند مكانهاى بيشترى را در طى روز بروند و انزوا و ماندن در خانه ممكن است براى آنها سخت است (انيسى، Y •.ץ; اى و همكاران، (Y) (Y). همجِنين در تبيين اين يافته مى توان گفت جون اين مطالعه در هنگام سير نزولى و شروع كسب و كارهاى كم خطر در كرمانشاه همزمان بوده كه خود اين عامل باعث شده افراد برونگ ا توجهى

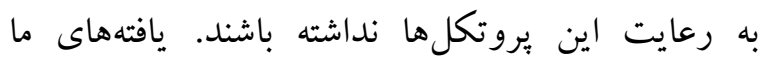
شواهدى را بر رابطه بين ويثز گهاى شخصيتى و رفتارهاى خود مراقبتى مرتبط با كرونا افزود. بعلاوه اين نتايج دادههاى را براى ارزيابى و مداخله روان شناختى در طول شيوع ويروس كرونا كه ممكن است ماهها ادامه داشته باشد فراهم نمود. اين مطالعه داراى جندين محدوديت بود. اول اينكه به خاطر همه گيرى بيمارى، ئزوهش بهصورت غيرحضورى و از طريق شبكهاى مجازى صورت گرفت و نظارت كامل بزوهشخر بر نحوه اجرا وجود نداشت. دوم اينكه با توجه به نبود برسشنامههاى استاندارد شده از يكك برسشنامه خود ساخته استفاده كرديم. سوم اينكه بسيارى از افرادى كه توانايى دسترسى به شبكهاى مجازى مثل واتساب نداشتند در اين مطالعه شر كت نكردند. درنهايت ما فقط ويز گیىهاى شخصيتى و

${ }^{5}$ - Zachenkowski
تائيد مى كنند. هماهنگك با ساير مطالعات افرادى كه نمره بالايى در وظيفهشناسى مى گيرند رفتارهاى خود مراقبى مثل فاصله گذارى اجتماعى و رفتارهاى دست شستن و استفاده از ماسكك را رعايت مى كنند (عبدالرحمن'،

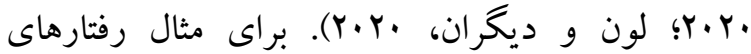
همدلانه مثل اعتماد اجتماعى و مسئوليت بذيرى اجتماعى با پايبندى بيشتر به قرنطينه و احتكار كمتر ارتباط دارند

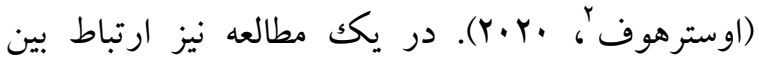
صفات شخصيتى و فاصله كذارى اجتماعى نشان داد كه توافق بذيرى ارتباط منفى با فاصله كذارى اجتماعى دارد و وظيفهشناسى و روان رنجور خويى رابطه مثبى با رعايت فاصله گذارى اجتماعى نشان دادند (عبدالرحمن، r.Y. بيشترى دارند و ترجيح مىدهند در رويدادهاى اجتماعى، مانند فعاليتهاى داوطلبانه و تعاملات اجتماعى شركت كنند، براى جلو گيرى از بيمارىهاى عفونى، فاصله كذارى اجتماعى ر را كمتر رعايت مئى كنتد (عبدالرحمن، ·.Y.Y.). از سوى ديخر افرادى كه تمايل بيشترى به رعايت هنجارهاى اجتماعى دارند و كسانى كه احساسات اضطرابآور و ترس آور دارند تمايل به حفظ فاصله گيرى اجتماعى دارند (عبدالرحمن، ·.Y.Y). همجنين يافتها نشان دادند كه ويز گیى برون گرايى هيج ارتباطى با رعايت فاصله گذارى اجتماعى و دست شستن ندارد كه همسو با مطالعه كاروالو و همكاران است كه نشان دادند عدم رعايت اين توصيهها با صفت برون گر ايى

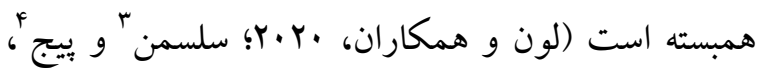
و Y...... بعلاوه اين يافته با مطالعه زاجنكوسكى

\footnotetext{
1- Abdelrahman

2. Osterhoff

3- Saulsman

4. Page
} 
طريق شبكه هاى مجازى صورت گرفت و نظارت كامل يثزوهش گر بر نحوه اجرا وجود نداشت. دوم اينكه با توجه

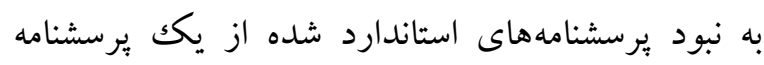

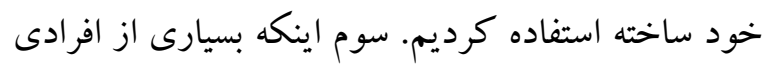
كه توانايى دسترسى به شبكهاى مجازى مثل واتساب نداشتند در اين مطالعه شركت نكردند. در نهايت ما فقط به له ويز كىهاى شخصيتى و تفاوتهاى جنسى را بررسى كرديم در صورتى كه متغيرهاى مهم ديخرى نظير بيشينه تحصيلى، دانش بزشكى كلى افراد يا صرفا بى اعتمادى به دولت كه مى تواند بر رعايت رفتارهاى خود مراقبتى تاثير بحذارند را در نظر نخرفتيم. بعلاوه ارزشهاى اجتماعى، دونى

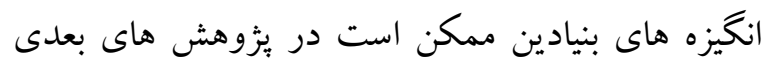

$$
\text { براى بررسى ارزشمند باشند. }
$$

\section{سياسگزارى}

از تمامى شركت كنند كان اين يثزوهش و و معاونت تحقيقات دانشگاه علوم بزشكى كرمانشاه و همجنين از مدافعان سلامت كه در اين ايام همه كيرى كرونا از جان و ئرسي

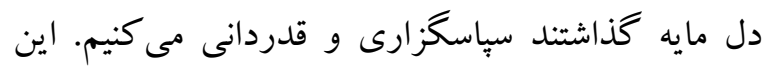
يثزوهش توسط كميته اخلاق دانشخاه علوم بزشكى كرمانشاه با كد IR.KUMS.REC.1399.490 تائيد

$$
\text { و ثبت شده است. }
$$

\section{References}

Abdelrahman M. (2020). Personality traits, risk perception, and protective behaviors of Arab residents of Qatar during the COVID-19 pandemic. Intemational Joumal of Mental Health and Addiction, 1-12. (In Persian)

Ai P, Liu Y, \& Zhao X. (2019). Big Five personality traits predict daily spatial behavior. Evidence from smartphone data. Personality and Individual Differences, 147, 285-291.
تفاوتهاى جنسى را بررسى كرديم درصورتى كه

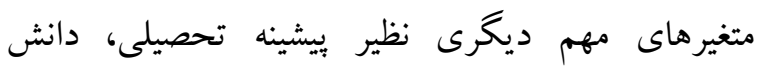

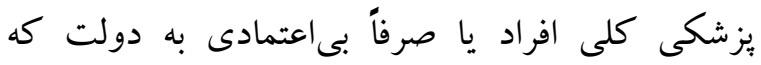
مىتواند بر رعايت رفتارهاى خود مراقبتى تأثير بحذارند را در نظر نگرفتيم. بعلاوه ارزشهاى اجتماعى، انخيزههاى

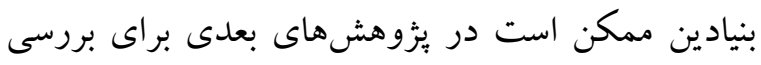

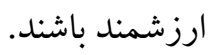

\section{نتيجه كيرى}

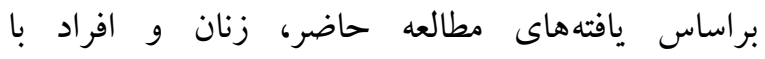

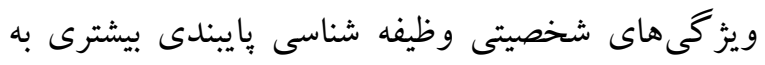
رفتارهاى خود مراقبتى مرتبط با كرونا داشتند اما يافتها

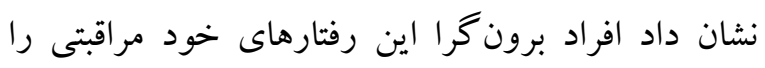

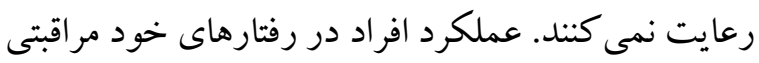
به عوامل متفاوتى بستخى دارد و متغيرهاى زيادى در اين عامل نقش دارند، اما نقش ويز كى هاى شخصيتى افراد و جنسيت از اهميت بالايى برخودارد است. انجام اين

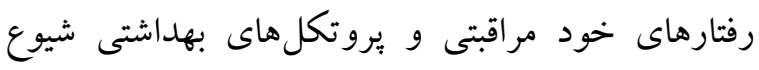
ويروس كرونا را كمتر و باعث كنترل آن تا زمان بيدا

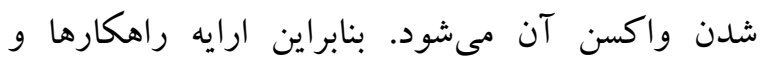
تكنيك هاى مناسب روان شناختى براى بالا بردن مسئوليت بذيرى افراد جامعه و همجنين آموزش به آنها از طريق رسانهاى جمعى ضرورى مىباشد. همجنين يافتهاى ما مى تواند براى سياستهاى سلامت عمومى و انجام مداخلاتى براى آكاهى بيشترمردم و در بيى آن بايبندى بيشتر به رفتارهاى خود مر اقبتى براى كنترل كرونا

$$
\text { ويروس مفيد باشد. }
$$

اين مطالعه داراى جندين محدوديت بود. اول اينكه بخاطر همه گيرى بيمارى، بزوهش به صورت غير حضورى و از 
Anderson RM, Heesterbeek H, Klinkenberg D, \& Hollingsworth TD. (2020). How will countrybased mitigation measures influence the course of the COVID-19 epidemic? The Lancet, 395(10228), 931-934.

Anisi J. (2012). Validity and reliability of NEO FiveFactor Inventory (NEO-FFI) on university students. Intemational Journal of Behavioral Sciences, 5(4), 351-355. (In Persian)

Bao Y, Sun Y, Meng S, Shi J, \& Lu L. (2020). 2019nCoV epidemic: address mental health care to empower society. The Lancet, 395(10224), e37-e38.

Bogg T, \& Roberts BW. (2004). Conscientiousness and health-related behaviors: a meta-analysis of the leading behavioral contributors to mortality. Psychological bulletin, 130(6), 887.

Cao W, Fang Z, Hou G, Han M, Xu X, Dong J, \& Zheng J. (2020). The psychological impact of the COVID-19 epidemic on college students in China. Psychiatry research, 112934.

Clark C, Davila A, Regis M, \& Kraus S. (2020). Predictors of COVID-19 voluntary compliance behaviors: An intemational investigation. Global Transitions, 2, 76-82.

Dupont WD, \& Plummer Jr WD. (1998). Power and sample size calculations for studies involving linear regression. Controlled clinical trials, 19(6), 589-601.

Goncalves AP, Zuanazzi AC, Salvador AP, Jaloto A, Pianowski G, \& Carvalho L. (2020). Preliminary findings on the associations between mental health indicators and social isolation during the COVID-19 pandemic. Archives of Psychiatry and Psychotherapy, 22(2), 10-19.

Kraus S, Clauss T, Breier M, Gast J, Zardini A, \& Tiberius V. (2020). The economics of COVID-19: initial empirical evidence on how family firms in five European countries cope with the corona crisis. International Journal of Entrepreneurial Behavior \& Research.

Liao Q, Cowling B, Lam WT, Ng MW, \& Fielding R. (2010). Situational awareness and health protective responses to pandemic influenza $\mathrm{A}$
(H1N1) in Hong Kong: a cross-sectional study. PLOS one, 5(10), e13350.

Lunn P, Belton C, Lavin C, McGowan F, Timmons S, \& Robertson D. (2020). Using behavioural science to help fight the coronavirus. ESRI Working Paper No. 656 March 2020.

Meshram S, Gattani D, Shewale A, \& Bodele S. (2017). Association of Personality Traits with Oral Health Status: A Cross-Sectional Study. The Intemational Joumal of Indian Psychology, Volume 4, Issue 2, No. 95, 61.

Miguel FK, Machado GM, Pianowski G, \& De Francisco Carvalho L. (2020). Compliance with containment measures to the COVID-19 pandemic over time: Do antisocial traits matter? Personality and Individual Differences, 110346.

Mohammadpour M, Ghorbani V, Khoramnia S, Ahmadi SM, Ghvami M, \& Maleki M. (2020). Anxiety, Self-Compassion, Gender Differences and COVID-19: Predicting SelfCare Behaviors and Fear of COVID-19 Based on Anxiety and Self-Compassion with an Emphasis on Gender Differences. Iranian Joumal of Psychiatry. (In Persian)

Oosterhoff B. (2020). Psychological comelates of news monitoring, social distancing, disinfecting, and hoarding behaviors among US adolescents during the COVID-19 pandemic.

Park JH, Cheong HK, Son DY, Kim SU, \& Ha CM. (2010). Perceptions and behaviors related to hand hygiene for the prevention of H1N1 influenza transmission among Korean university students during the peak pandemic period. BMC Infectious Diseases, 10(1), 222.

Pennycook G, McPhetres J, Zhang Y, Lu JG, \& Rand DG. (2020). Fighting COVID-19 misinformation on social media: Experimental evidence for a scalable accuracy-nudge intervention. Psychological science, 31(7), 770-780.

Saulsman LM, \& Page AC. (2004). The five-factor model and personality disorder empirical literature: A meta-analytic review. Clinical psychology review, 23(8), 1055-1085. 
Spence R, Owens M, \& Goodyer I. (2012). Item response theory and validity of the NEO-FFI in adolescents. Personality and individual differences, 53(6), 801-807.

Tyler TR, \& Blader SL. (2003). The group engagement model: Procedural justice, social identity, and cooperative behavior. Personality and social psychology review, 7(4), 349-361.

Van Dijk S, Hanssen D, Naarding P, Lucassen P, Comijs H, \& Voshaar RO. (2016). Big Five personality traits and medically unexplained symptoms in later life. European Psychiatry, 38, 23-30.

Verity R, Okell LC, Dorigatti I, Winskill P, Whittaker C, Imai N, Cuomo-Dannenburg G, Thompson H, Walker PG, \& Fu H. (2020). Estimates of the severity of coronavirus disease 2019: a model-based analysis. The Lancet infectious diseases.

Wilder-Smith A, \& Freedman DO. (2020). Isolation, quarantine, social distancing and community containment: pivotal role for old-style public health measures in the novel coronavirus (2019-nCoV) outbreak. Joumal of travel medicine, 27(2), taaa020.

Yang Y, Li W, Zhang Q, Zhang L, Cheung T, \& Xiang YT. (2020). Mental health services for older adults in China during the COVID-19 outbreak. The LancetPsychiatry, 7(4), e19.

Zajenkowski M, Jonason PK, Leniarska M, \& Kozakiewicz Z. (2020). Who complies with the restrictions to reduce the spread of COVID-19?: personality and perceptions of the COVID-19 situation. Personality and Individual Differences, 166, 110199. 